\title{
Role of the Seasonal Cycle in Atrial Fibrillation Seen after Coronary Artery Bypass Surgery
}

\author{
Ersin Çelik ${ }^{*}$, Ahmet Rıfkı Çora' ${ }^{1}$, Kadir Burhan Karadem², Dinçer Uysal² \\ ${ }^{1}$ Isparta City Hospital Department of Cardiovascular Surgery, Isparta, Turkey \\ ${ }^{2}$ Suleyman Demirel University Department of Cardiovascular Surgery, Isparta, Turkey \\ Email: *dr.ersincelik@gmail.com
}

How to cite this paper: Çelik, E., Çora, A.R. Karadem, K.B. and Uysal, D. (2020) Role of the Seasonal Cycle in Atrial Fibrillation Seen after Coronary Artery Bypass Surgery. World Journal of Cardiovascular Surgery, 10, 91-99. https://doi.org/10.4236/wjcs.2020.106012

Received: May 30, 2020

Accepted: June 21, 2020

Published: June 24, 2020

Copyright $\odot 2020$ by author(s) and Scientific Research Publishing Inc. This work is licensed under the Creative Commons Attribution International License (CC BY 4.0).

http://creativecommons.org/licenses/by/4.0/

(c) (i) Open Access

\begin{abstract}
Background: We aimed to investigate the effect of seasons on atrial fibrillation that occurred after coronary bypass surgery operation. Method: $187 \mathrm{pa}-$ tients underwent coronary artery bypass operation in our clinic between July 2018 - July 2019. Isolated coronary artery bypass graft operation was performed with cardiopulmonary bypass to 179 of these patients. Forty three patients that developed atrial fibrillation after coronary bypass operation, demographic, laboratory findings and date of atrial fibrillation data investigated retrospectively. Results: Forty three patients developed atrial fibrillation after coronary artery bypass surgery. Forty one patients operated in winter, 48 in spring, 47 in summer, 43 in autumn and 13 patients developed atrial fibrillation in winter, $11(25.6 \%)$ in spring, $8(20.9 \%)$ in summer and $11(23.3 \%)$ in autumn respectively. There is no statistical significance found by $\mathrm{Z}$ test that performed for all seasons for atrial fibrillation. Conclusion: There are many reasons that could play role on developing atrial fibrillation after coronary artery bypass surgery. There are many publications that report vitamin $\mathrm{D}$ deficiency as a reason for developing atrial fibrillation after coronary bypass surgery. In our study, we did not evaluate a relationship between the development of post operative atrial fibrillation and seasons.
\end{abstract}

\section{Keywords}

Atrial Fibrillation, Coronary Artery Bypass Grafting, Vitamin D, Season

\section{Introduction}

Atrial fibrillation (AF) is the most frequent sustained cardiac arrythmia affected about $1.5 \%-2 \%$ of the population [1]. It is also the most frequent arrythmia seen after coronary artery bypass grafting (CABG) operations affected about $15 \%-60 \%$ of the patients [2]. Complications including stroke, pneumonia, 
shortness of breath can be seen in patients that developed AF. For these reasons, morbidity, mortality and also prolongation in hospital stay and overall health costs could increase [3].

There are many risk factors that affect post operative atrial fibrillation (POAF) seen after cardiac surgery procedures including age, obesity, hypertension (HT), cardiac failure, right coronary artery lesions, concomitant valve problems with coronary problems, hypomagnesemia and cessation of beta blocker medications [3] [4] [5]. There are many publications that reported the relationship between low serum vitamin-D levels and POAF [6] [7]. D-vitamin levels show diversion among seasons and regions of the earth that; levels decreased in December-February on northern regions and in June-August on southern regions [8]. There is no reported relationship between POAF and seasons seen after CABG surgery except Ada and colleagues in literature [9]. We investigated the relationship of POAF and seasons among CABG operations that performed in winter and summer seasons that D-vitamin levels are lowest and highest on Northern region of the earth.

\section{Material and Method}

After permission was taken from Süleyman Demirel University ethic committee numbered 05.12.2019/344, data were collected from two different cardiovascular surgery centers between July 2018 - July 2019 among 187 patients that performed CABG operation retrospectively. The written consent form was obtained from all the patients. Data were included medications, comorbidities, cross clamp and total bypass times, echocardiographic findings, season that CABG operation performed, collected from hospitals' databases.

Patients have preoperative AF, combined valve and CABG surgery, off pump surgery and patients who continue to use D-vitamin preoperativeley were excluded. There was 1 patient who developed POAF excluded because of the development of Wolf Parkinson White syndrome. Forty three patients that developed POAF included in the study. Routine blood tests, respiratory function tests, echocardiography, carotid duplex ultrasonography, chest x-ray, electrocardiogram were performed after taking medical history and routine physical examination of all patients that planned CABG surgery. All patients were examined for chronic obstructive pulmonary disease (COPD) by chest disease specialist with pulmonary function tests, and patients that couldn't perform pulmonary function test, examined with arterial blood gas and physical examination.

Operative Technique

Median sternotomy was applied under general anesthesia in all patients. Cardiopulmonary bypass was performed by using aortocaval cannulation technique in all patients following systemic heparin administration (300 IU/kg). Cardiac arrest was achieved by using hypothermic, hyperkalemic blood cardioplegia and topical hypothermia. Surgery was performed under moderate systemic hypothermia $\left(32^{\circ} \mathrm{C}\right)$. Cardiopulmonary bypass flow was maintained at $2.2-2.5$ $\mathrm{L} / \mathrm{min} / \mathrm{m}^{2}$, mean perfusion pressure was maintained between 50 and $80 \mathrm{~mm} \mathrm{Hg}$, 
and hematocrit level was maintained at 20\% - 25\% during cardiopulmonary bypass. Cardiac arrest maintained by using intermittent antegrade cold blood cardioplegia infusions. In patients that had low ejection fraction (EF), multivessel disease (MVD) and poor ventricular function, continuous retrograde cold blood cardioplegia infusion was given in addition to antegrade intermittent cold blood cardioplegia. Left internal mammary artery (LIMA) was used in all patients for revascularization of left anterior decending artery. Saphenous vein graft was used for grafting of other coronary arteries. Warm blood cardioplegia was given in all patients just before removing the cross-clamp. All proximal anastomosis were performed by using side clamp. All early postoperative patient follow ups were done in third degree cardiovascular surgery intensive care unit. After cardiac and hemodynamic stabilization, all patients were taken to the cardiovascular surgery service following the removal of all chest tubes, central venous lines and urinary catheters.

Postoperative Atrial Fibrillation

All patients were monitored in the intensive care unit after surgery with a 5-lead monitoring system Philips IntelliVue MX800 (Philips, Boeblingen, Germany) using the standard lead II configuration. After discharge from the intensive care unit, patients were followed up 6 - 8 times daily in the service. Following surgery, subsequent 12-lead electrocardiograms were obtained daily from each patient until discharge postoperatively, and also if a patient manifested with symptoms of palpitations or an irregular pulse, a 12-lead electrocardiography Mindray Bene Heart R12 (Shenzhen Mindray Bio-Medical Electronics Co. Ltd., Shenzhen, China) was performed to diagnose the arrhythmia. New-onset postoperative AF was described as AF (according to the established Society of Thoracic Surgeons definition) occurring during hospitalization after CABG in a patient with no history of AF. Episodes of AF were treated according to clinical routines which included pharmacological interventions with intravenous amiodarone or, if contraindicated, with an oral $\beta$-blocker (metoprolol) and/or with electrical therapies like cardioversion.

\section{Statistical Analyses}

All data analyses were performed with IBM SPSS v23 (StataCorp LP, College Station, TX, USA) and Minitab 16 (LLC, state college, Pennssylvania, USA) programs. Kolmograv-Smirnov test, Qi-square test, Kruskal-Wallis test and Z-test were used for statistical analyses of the data.

\section{Results}

Forty four of 179 (25\%) patient who underwent CABG surgery developed POAF. POAF was observed $25.6 \%$ in spring, $20.9 \%$ in summer, $23.3 \%$ in autumn and $30.2 \%$ in winter respectively. $\mathrm{EF}$, glomerular filtration rates, left atrial diameters, total cross clamp and bypass times, preoperative calcium and potasium levels and concomitant diseases of patients listed in Table 1 and Table 2.

The distribution graphics of POAF according to seasons and months is shown 
in Figure 1 and Figure 2.

The seasonal distribution of patients underwent coronary bypass operation, ratios of developing POAF and total numbers were shown in Table 3.

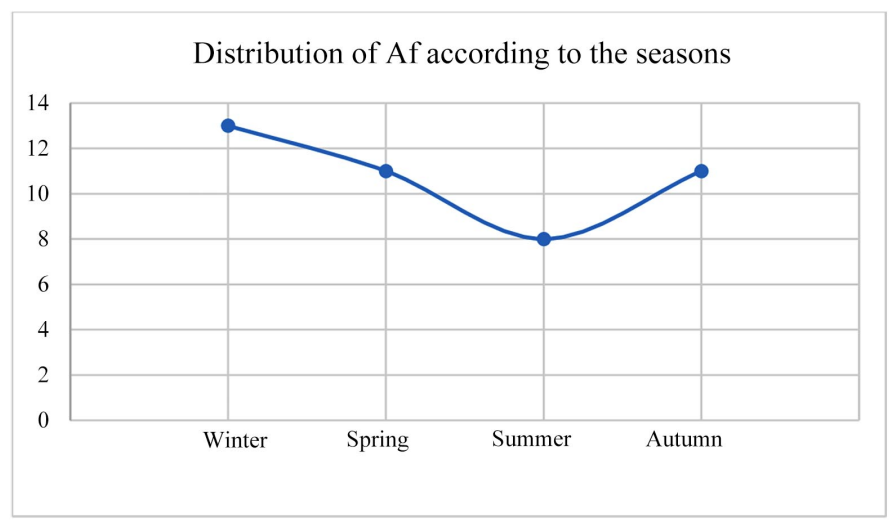

Figure 1. Distribution of Af according to seasons. Af=Atrial Fibrillation.

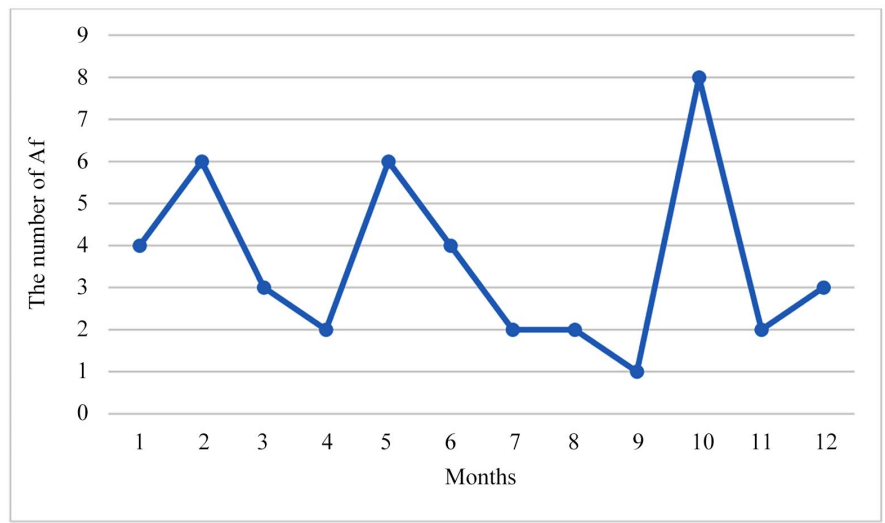

Figure 2. Distribution of atrial fibrillation by months.

Table 1. Demographic data.

\begin{tabular}{cccccc}
\hline & Patient Number & Minimum & Maximum & Mean & Std. Deviation \\
\hline Age & 43 & 51 & 85 & 66.8837 & 7.36856 \\
Ejection fraction \% & 43 & 30 & 65 & 55.4651 & 8.56168 \\
Gfr & 43 & 44 & 106 & 78.186 & 15.15987 \\
$\begin{array}{c}\text { Diameter of Left Atrium } \\
\quad(m m)\end{array}$ & 43 & 26 & 56 & 36.7674 & 6.36522 \\
$\begin{array}{c}\text { Number of Bypass Grafts } \\
\quad 43\end{array}$ & 13 & 5 & 2.6744 & 0.83726 \\
$\quad$ Time of Af & 43 & 0 & 18 & 2.6512 & 4.11087 \\
Cross Clamp Time (mnt) & 43 & 86 & 51.5349 & 15.13644 \\
Total Bypass Time (mnt) & 43 & 39 & 147 & 87.9535 & 26.39981 \\
$\quad$ Level of calcium & 43 & 9.77 & 10.3 & 8.5326 & 1.76451 \\
$\quad$ Level of potassium & 43 & 3.5 & 4.2 & 5.0442 & 1.83009 \\
\hline
\end{tabular}

$\mathrm{Gfr}=$ Glomeruler filtration rate, $\mathrm{Af}=$ Atrial fibrillation. 
Table 2. Demographic data.

\begin{tabular}{|c|c|c|c|}
\hline & & Number & Percent \\
\hline \multirow[t]{2}{*}{ Sex } & Male & 36 & 83.7 \\
\hline & Female & 7 & 16.3 \\
\hline Diabetes & Negative & 21 & 48.8 \\
\hline Mellitus & Positive & 22 & 51.2 \\
\hline \multirow{2}{*}{ Hypertension } & Negative & 28 & 65.1 \\
\hline & Positive & 15 & 34.9 \\
\hline \multirow{2}{*}{ COPD } & Negative & 29 & 67.4 \\
\hline & Positive & 14 & 32.6 \\
\hline \multirow{2}{*}{ Chronic renal disease } & Negative & 41 & 95.3 \\
\hline & Positive & 2 & 4.7 \\
\hline \multirow{2}{*}{ Use of statins } & Negative & 38 & 88.4 \\
\hline & Positive & 5 & 11.6 \\
\hline $\mathrm{ACE}$ & Negative & 37 & 86.0 \\
\hline inhibitory & Positive & 6 & 14.0 \\
\hline \multirow{2}{*}{ Beta Blocker } & Negative & 19 & 44.2 \\
\hline & Positive & 24 & 55.8 \\
\hline Peripheral artery & Negative & 38 & 88.4 \\
\hline Disease & Positive & 5 & 11.6 \\
\hline
\end{tabular}

$\mathrm{COPD}=$ Chronic Obstructive pulmonary disease, $\mathrm{ACE}=$ Angiotensin-converting enzyme.

Table 3. Atrial fibrillation numbers of postoperative coronary bypass graft surgery.

\begin{tabular}{ccccccc}
\hline & Center 1 & \multicolumn{2}{c}{ Center 2 } & \multicolumn{2}{c}{ Total } \\
\cline { 2 - 7 } & Cabg & Af & Cabg & Af & Total Cabg & Total Af \\
\hline Summer & 23 & 5 & 24 & 3 & 47 & 8 \\
Spring & 32 & 6 & 16 & 5 & 48 & 11 \\
Winter & 24 & 6 & 17 & 7 & 41 & 13 \\
Autumn & 20 & 5 & 23 & 6 & 43 & 11 \\
\hline
\end{tabular}

Af $=$ Atrial fibrillation, Cabg $=$ Coronary artery bypass graft.

Distribution of the data that shows the onset of the POAF were not uniform. The differences of seasons' ranks according to Kruskal-Wallis test were not statistically significant. The ratio of POAF in winter and in summer to all patients performed CABG operation were 8/47 and 13/41 respectively and not statistically significant according to $\mathrm{Z}$ test $(p=0.107)$. No significance revealed when all seasons compared to each other according to $\mathrm{Z}$ test. And also there is no significance was observed when 2 centres were compared to each other and in their own. 


\section{Discussion}

Vitamin- D is a steroidal structured vitamin that synthesized by skin when exposed to ultraviolet sun light [10]. Today, physiologic mechanisms of the seasonal differentiations of the vitamin-d levels of the human body were totally revealed [11] [12]. According to several reports in Turkey and worldwide, highest vitamin- $d$ levels were seen in summer and autumn, the lowest levels were seen in winter and spring in northern hemisphere regions [13]-[18].

The main mechanism of vitamin $\mathrm{d}$ is bone development and maintenance of the nature of the bones. But according to several studies published in recent years, vitamin-d levels were associated with some clinical cases including diabetes, hypertension, cardiovascular disorders, multiple sclerosis, asthma, depression, several cancer types and some autoimmune disorders [19] [20] [21].

Because of the effects of vitamin-D on cardiovascular system, attention was focused on this vitamin among cardiologists and cardiovascular surgeons in recent years. Although vitamin-D is known to have relationship with cardiovascular disorders, protective effects of this vitamin for cardiovascular system and mechanisms of protection could not yet fully understood. Effects on renin-angiotensin system, suppression of inflammatory cytokines, direct effects on vascular wall and regulation of calcium accumulation in vascular smooth muscles with regulation of parathormone levels were studied mechanisms about the possible effects of the vitamin-D on cardiovascular system [22] [23].

Many studies reported vitamin-D deficiency and its relations with AF in recent years [1] [2] [5]. And also, there were many studies published about the relationship of vitamin-D deficiency and AF seen after CABG operation [2]-[7] [24] [25]. In our study, although we found the significant rise in POAF after CABG operation in winter that vitamin-D levels are lowest, in statistical analyses no significance was found. We searched the literature for POAF after CABG surgery and found no publications except Ada et al's report [9]. In this report Ada et al. reported POAF after CABG surgery $17.5 \%$ in winter and $5.5 \%$ in summer.

We have some limitations in our study. First of all, our center is a new-onset cardiovascular center and because of this reason limited amount of patients in limited time period can be studied. Patients diagnosed as POAF at hospitalisation period. Some patients could develope POAF after discharge from hospital and cannot be diagnosed for this reason.

\section{Conclusion}

There were plenty of factors that affect POAF after CABG surgery. One of these factors is vitamin-D deficiency and there were many studies reported vitamin-D deficiency as one of the causes of this disorder. There were limited amount of studies in literature about relationship between POAF and vitamin-D deficiency. And also we found one study about the relationship between seasons and POAF after CABG. In our study, we found no difference between POAF and seasons. 
But, there is need to further evaluation for the relationship of POAF after CABG surgery and seasons with multicentre randomized clinical trials. And if a relationship confirmed with POAF and seasons by this clinical trials, checking the vitamin-D blood levels before CABG operation and vitamin-D replacement can be added to medical therapy, if needed, especially in winter season. By this means, we think that extra protection could be provided in addition to the other preventive strategies for POAF after CABG surgery.

\section{Acknowledgements}

We especially thank to Biostatistic specialist Assct. Professor Özgür Koşkan for contributing the study data.

\section{Authors Contributions}

1) substantial contributions to conception and design, acquisition of data, or analysis and interpretation of data; 2) drafting the article or revising it critically for important intellectual content; and 3) final approval of the version to be published.

Ersin Çelik: 1, 2, 3; Ahmet Rıfkı Çora: 1, 2, 3; Kadir Burhan Karadem: 1, 2, 3; Dinçer Uysal: 1.

\section{Funding}

The authors received no financial support for the research and/or authorship of this article.

\section{Conflicts of Interest}

The authors declared no conflict of interest with respect to the authorship and/or publication of this article.

\section{References}

[1] Foussas, S. (2016) Acute Coronary Syndromes and Atrial Fibrillation. Hellenic Journal of Cardiology, 57, 141-142. https://doi.org/10.1016/j.hjc.2016.05.001

[2] Yadava, M., Hugley, A.B. and Crawford, T.C. (2014) Postoperative Atrial Fibrillation: Incidedce, Mechanisms, and Clinical Correlates. Cardiology Clinics, 32, 627-636. https://doi.org/10.1016/j.ccl.2014.07.002

[3] Phan, K., Ha, H.S., Phan, S., Medi, C., Thomas, S.P. and Yan, T.D. (2015) New-Onset Atril Fibrillation Following Coronary Bypass Surgery Predicts Long-Term Mortality: A Systematic Review and Meta-Analysis. European Journal of Cardio-Thoracic Surgery, 48, 817-824. https://doi.org/10.1093/ejcts/ezu551

[4] Frendl, G., Sodickson, A.C., Chung, M.K., Waldo, A.L., Gersh, B.J., Tisdale, J.E., et al. (2014) American Association for Thoracic Surgery: 2014 AATS Guidelines for the Prevention and Management of Perioperatif Atrial Fibrillation and Flutter for Thoracic Surgical Procedures. The Journal of Thoracic and Cardiovascular Surgery, 148, e153-e193. https://doi.org/10.1016/j.jtcvs.2014.06.036

[5] Shen, J., Lall, S., Zheng, V., Buckley, P., Damiano, R.J. and Schuessler, R.B. (2011) The Persistent Problem of New-Onset Postoperative Atrial Fibrillation: A Sin- 
gle-Institution Experience over Two Decades. The Journal of Thoracic and Cardiovascular Surgery, 141, 559-570. https://doi.org/10.1016/j.jtcvs.2010.03.011

[6] Emren, S.V., Aldemir, M. and Ada, F. (2016) Does Deficiency of Vitamin D Increase New-Onset Atrial Fibrillation after Coronary Artery Bypass Grafting Surgery? The Heart Surgery Forum, 19, 180-184. https://doi.org/10.1532/hsf.1531

[7] Gode, S., Aksu, T., Demirel, A., Sunbul, M., Gul, M., Bakır, I., et al. (2016) Effect of Vitamin D Deficiency on the Development of Postoperative Atrial Fibrillation in Coronary Artery Bypass Patients. Journal of Cardiovascular and Thoracic Research, 8, 140-146. https://doi.org/10.15171/jcvtr.2016.29

[8] Bolland, M.J., Chiu, W.W., Davidson, J.S., Grey, A., Bacon, C., Gamble, G.D., et al. (2008) The Effects of Seasonal Variation of 25-Hydroxyvitamin D on the Diagnosis of Vitamin D Insufficiency. New Zealand Medical Journal, 121, 63-74.

[9] Ada, F. and Polat, V. (2019) Is There a Seasonal Feature of New-Onset Atrial Fibrillation after Coronary Artery Bypaa Graft Surgery? Cumhuriyet Medical Journal, 41, 563-568. https://doi.org/10.7197/cmj.vi.610344

[10] Cutolo, M. and Otsa, K. (2008) Vitamin D, Immunity and Lupus. Lupus, 17, 6-10. https://doi.org/10.1177/0961203307085879

[11] Maxwell, J.D. (1994) Seasonal Variation in Vitamin D. Proceedings of the Nutrition Society, 53, 533-543. https://doi.org/10.1079/PNS19940063

[12] Webb, A.R., Kline, L. and Holick, M.F. (1988) Influence of Season and Latitude on the Cutaneous Synthesis of Vitamin D3: Exposure to Winter Sunlight in Boston and Edmonton Will Not Promote Vitamin D3 Synthesis in Human Skin. Journal of Clinical Endocrinology and Metabolism, 67, 373-378. https://doi.org/10.1210/jcem-67-2-373

[13] Telo, S., Kaman, D. and Akgöl, G. (2017) Alteration of Vitamin D Levels According to Age, Gender and Season in Elazığ. Firat Medical Journal, 22, 29-33.

[14] Öğüş, E., Sürer, H., Kılınç, A.Ş., Fidanc1, V., Yılmaz, G., Dindar, N. and Ark, V.E. (2015) D vitamini düzeylerinin aylara, cinsiyete ve yaşa göre değerlendirilmesi. Ankara Medical Journal, 15, 1-5. https://doi.org/10.17098/amj.88875

[15] Hekimsoy, Z., Dinç, G., Kafesciler, S., Onur, E., Güvenç, Y., Pala, T., et al. (2010) Vitamin D Status among Adults in the Aegean Region of Turkey. BMC Public Health, 10, Article No. 782. https://doi.org/10.1186/1471-2458-10-782

[16] Guessous, I., Dudler, V., Glatz, N., Theler, J.M., Zoller, O., Paccaud, F., et al. (2012) Vitamin D Levels and Associated Factors: A Population-Based Study in Switzerland. Swiss Medical Weekly, 142, w13719. https://doi.org/10.4414/smw.2012.13719

[17] Klenk, J., Papp, K., Denkinger, M.D., Nagel, G., Nikolaus, T., Peter, R., et al. (2013) Seasonality of Vitamin D Status in Older People in Southern Germany: Implication for Assessment. Age and Ageing, 42, 404-408. https://doi.org/10.1093/ageing/aft042

[18] Vuistiner, P., Rousson, V., Henry, H., Lescuyer, P., Boulat, O., Gaspoz, J.M., et al. (2015) A Population-Based Model to Consider the Effect of Seasonal Variation on Serum 25(OH)D and Vitamin D Status. BioMed Research International, 2015, Article ID: 168189. https://doi.org/10.1093/ageing/aft042

[19] Thacher, T.D. and Clarke, B.L. (2011) Vitamin D Insufficiency. Mayo Clinic Proceedings, 86, 50-60. https://doi.org/10.4065/mcp.2010.0567

[20] Holick, M.F. (2007) Vitamin D Deficiency. The New England Journal of Medicine, 357, 266-281. https://doi.org/10.1056/NEJMra070553

[21] Holick, M.F. (2003) Vitamin D: A Millenium Perspective. Journal of Cellular Biochemistry, 88, 296-307. https://doi.org/10.1002/jcb.10338 
[22] Zittermann, A., Schleithoff, S.S. and Koerfer, R. (2007) Vitamin D and Vascular Calcification. Current Opinion in Lipidology, 18, 41-46. https://doi.org/10.1097/MOL.0b013e328011c6fc

[23] Fitzpatrick, L.A., Bilezikian, J.P. and Silverberg, S.J. (2008) Parathyroid Hormone and the Cardiovascular System. Current Osteoporosis Reports, 6, 77-83. https://doi.org/10.1007/s11914-008-0014-8

[24] Cerit, L., Kemal, H., Gulsen, K., Ozcem, B., Cerit, Z. and Duygu, H. (2017) Relationship between Vitamin D and the Development of Atrial Fibrillation after On-Pump Coronary Artery Bypass Graft Surgery. Cardiovascular Journal of Africa, 28, 104-107. https://doi.org/10.5830/CVJA-2016-064

[25] Öztürk, S. and Öztürk, İ. (2020) Atrial Fibrillation after Cardiac Surgery and Preoperative Vitamin D Levels: A Systematic Review and Meta-Analysis. Turk Gogus Kalp Dama, 28, 101-107. https://doi.org/10.5606/tgkdc.dergisi.2020.18387 